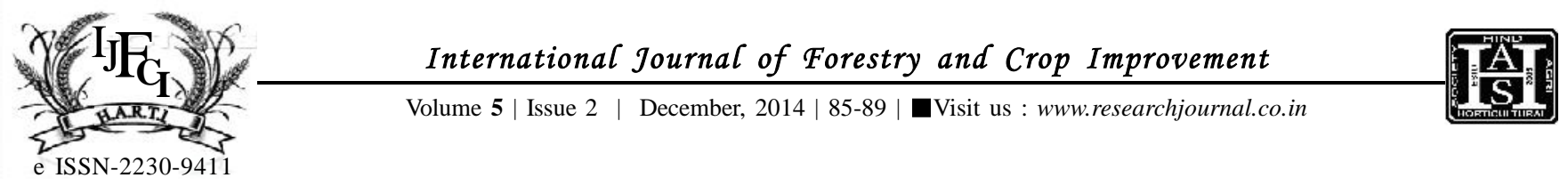

\title{
A Case Study
}

\section{Wild edible tuber and root plants available in bastar region of Chhattisgarh}

\author{
AJAY BANIK, SHARAD NEMAand DEOSHANKAR
}

\begin{abstract}
Natural forest is the source of supplies of various plants of tuberous and roots importance that provides carbohydrates and some minerals and are often important ingredients in traditional medicines. They used as drought and famine foods, not only because they survive in low rainfall periods, but can also be an important source of water. Looking to the importance of wild tuberous crop in the tribal dominating region of the State an ethno botanical study was conducted to document and compile the wild edible tubers that had been observed and investigated in Central part of Bastar region of Chhattisgarh State. So that their importance, traditional uses could be realized. A total of 22 wild edible tubers were identified and recorded as food sources during the study period were Amorphophallus paeoniifolius, Asparagus racemosus, Chlorophytum borivilianum, Colocasia esculenta, Costus speciosus, Curculigo orchioides, Curcuma amada, Curcuma angustifolia, Curcuma caesia, Dendrocalamus strictus, Dioscorea alata, Dioscorea bulbifera, Dioscorea hispida, Dioscorea oppositifolia, Dioscorea pentaphylla, Dioscorea bulbifera var. pulchella, Hibiscus rugosus, Ipomoea batatas, Leea macrophylla, Pueraria tuberosa, Scirpus grossus, Urginea indica. Dioscorea or commonly known as yam was reported to be one of the major food sources in Bastar region. It was noticed that Dioscorea available as major tuber crops and highly utilized tuber species. The majority of villagers used Dioscorea in many ways in their life such as for food, medicinal purposes and fish poison. The 22 edible tuberous and root plants were belongs to the 13 families out of which Dioscoreaceae, Zingiberaceae, Liliaceae and Araceae had more than one identified plants whereas the families like Costaceae, Asparagaceae, Hypoxidaceae, Poaceae, Leeaceae, Fabaceae, Cyperaceae, Malvaceae, Convolvulaceae had only one edible tuber plant during period of study. The wild tubers are the dietary food and of seasonal resources of the tribals in forest dominating areas. Although the popularity of these wild tubers has declined, it is considered that special attention should be given to them in order to maintain and improve this important source of food supply in the area. This paper dealt with the wild edible tubers plant utilized by the tribal's of Bastar for their sustenance. The wild edible tubers plant of Bastar illustrated and documented for their utilization pattern.
\end{abstract}

KEY WORDS : Indigenous knowledge, Tubers, Kand, Root crops, Yams, Bastar, Staple food, Tribal

How to cite this Article : Banik, Ajay, Nema, Sharad and Shankar, Deo (2014). Wild edible tuber and root plants available in bastar region of Chhattisgarh. Internat. J. Forestry \& Crop Improv., 5 (2) : 85-89.

Article Chronical : Received : 04.09.2014; Accepted : 26.11.2014

\section{MEMBERS OF RESEARCH FORUM}

Address of the Correspondence :

SHARAD NEMA, School of Studies Forestry and Wildlife, Bastar

University, JAGDALPUR (C.G.) INDIA

Email: sharadnema77@ rediffmail.com

Address of the Coopted Authors :

AJAY BANIK, School of Studies Forestry and Wildlife, Bastar University, JAGDALPUR (C.G.) INDIA

Email: ajaybanik07@gmail.com

DEO SHANKAR, AICRP on Tuber Crops, S.G. College of Agriculture and Research Station (IGKV) JAGDALPUR (C.G.) INDIA

Email: deo1975ram@gmail.com,deotc@yahoo.com 